COMPETITOR: Jurnal Pendidikan Kepelatihan Olahraga

Volume 13 Number 1 Year 2021

e-ISSN: 2657-0734 \& p-ISSN: 2085-5389

This work is licensed under a Creative Commons Attribution 4.0 International License

\title{
Analysis Of Adaptive Physical Education Learning In The Covid-19 Pandemic Period at Ketapang District
}

\author{
Ade Rahmat \\ Physical Education, Health and Recreation Study Program/ IKIP PGRI Pontianak/Indonesia \\ Ampera Street No. 88, Pontianak City, West Kalimantan, Indonesia \\ mradde16@gmail.com
}

Received: January 21, 2021; Reviewed: February 09, 2021; Accepted: February 21, 2021;

Published: February 28, 2021

\begin{abstract}
Covid-19 has a real impact on the learning activities of Physical Education subject teachers in the Ketapang Regency. This study aims to describe the circumstances or conditions regarding the implementation of physical education learning for students with special needs (Adaptive Physical Education) during the Covid-19 pandemic in the Ketapang Regency, West Kalimantan Province. This research is research with a quantitative approach with a survey method. The sample in this study were physical education teachers in Ketapang Regency, totaling 14 teachers from 14 elementary schools from all physical education teachers in Ketapang Regency who carried out Adaptive learning. The research instrument used in this study was an online questionnaire using a validated google formula. The data analysis used in this research is descriptive quantitative research data analysis. Based on the results of the study, there were 14 elementary schools from 7 districts in Ketapang Regency which implemented adaptive physical education during the pandemic. $92.86 \%$ of teachers have been guided by the subject curriculum, 60.71\% of respondents thought that the 2013 curriculum, 80.36\% of Physical Education teachers made Prota instruments, while $73.21 \%$ had made Promes, and 76.79\%. Making RPP with format 1. It is concluded that Adaptive Physical Education Learning in Ketapang Regency has been implemented online, where there are still obstacles, namely difficulties with an internet connection, low adaptive physical education learning assistance by parents, and the lack of ability to modify learning methods during the Covid-pandemic. So that learning becomes less effective.
\end{abstract}

Keywords: Adaptive Physical Education Learning; Covid-19 Pandemic Period; Ketapang District.

\section{INTRODUCTION}

Based on the Circular of the Secretary-General of the Ministry of Education and Culture No. 15 of 2020, it is explained that the objectives of implementing Learning from Home during the Covid-19 pandemic emergency include ensuring the fulfillment of students' rights to get educational services during the Covid-19 pandemic period, protecting education unit residents from the adverse effects of Covid-19, preventing transmission and the spread of Covid-19 in educational units, and ensuring the fulfillment of psychosocial support for educators, students, and parents/guardians. This 
Analysis Of Adaptive Physical Education Learning In The Covid-19 Pandemic Period at Ketapang District

policy becomes a guide in the implementation of distance learning that is carried out in elementary schools throughout the Ketapang Regency.

Covid-19 has a real impact on the learning activities of teachers of Physical Education subjects in the Ketapang Regency. Teachers who are accustomed to carrying out learning activities outside the room, physical activities outside the room, must change teaching methods, assessment methods and make adjustments to distance learning facilities and infrastructure. Persons with disabilities are people who have long-term physical, mental, intellectual, or sensory limitations, where when faced with various obstacles, this can make it difficult for them to participate fully and effectively in a society based on equal rights (Wijayanti, Soegiyanto, \& Nasuka, 2016). Students with disabilities are also healthy students and should receive the same attention as normal students. In line with (Ragil, 2016) normal students or those with special needs will both get physical education, where through adaptive physical education students with special needs can be facilitated.

Good physical education learning can create educational interactions between students with special needs and their environment, such as; interaction with teachers, materials, methods, facilities and infrastructure, learning media, social environment, and so on (Ragil, 2016). Like normal students, students with special needs also deserve the same attention by physical education teachers in schools, because based on the convention regarding the rights of persons with disabilities contained in law number 19 of 2011 concerning the ratification of the convention on the right of persons with disabilities, that there is no longer any mention of persons with disabilities but instead they are replaced by persons with disabilities. It is hoped that carrying out sports for people with disabilities can be used as a medium for developing their potential, talents, and interests. This study aims to describe the circumstances or conditions regarding the implementation of physical education learning for students with special needs (Adaptive Physical Education) during the Covid-19 pandemic in the Ketapang Regency, West Kalimantan Province.

\section{METHOD}

This research is a research with a quantitative approach with a survey method, where this study aims to provide an overview of the actual conditions in a population. This research was conducted from December 2020 to January 2021 in Ketapang 
Analysis Of Adaptive Physical Education Learning In The Covid-19 Pandemic Period at Ketapang District

Regency. The sample in this study were physical education teachers in Ketapang Regency, totaling 14 teachers from 14 elementary schools from all physical education teachers in Ketapang Regency who carried out Adaptive learning.

The total sample technique is used in determining the sample, where the sample is taken from the entire population. The number of research subjects conducted is less than 100 people, so all samples are used. The research instrument used in this study was an online questionnaire using the google formula. The instrument used has been tested by an expert lecturer in Physical Education at IKIP PGRI Pontianak. Then the questionnaire that had been developed was distributed to physical education teachers in elementary schools throughout Ketapang Regency.

The data analysis used in this research is descriptive quantitative research data analysis. This analysis was used to determine the level of implementation of physical education learning for students with special needs (Adaptive Physical Education) during the Covid-19 pandemic in elementary schools throughout the Ketapang Regency.

\section{RESULTS AND DISCUSSION}

Based on online questionnaire data distributed to several teachers and elementary schools in Ketapang Regency, information was obtained that there were 14 elementary schools from 7 districts in Ketapang Regency which implemented adaptive physical education during the pandemic. The distribution of the number of schools implementing adaptive learning during the pandemic can be seen in Table 1 .

Table 1.

Distribution of Primary Schools for Research in Ketapang District

\begin{tabular}{|c|c|c|}
\hline No. & Sub-districts in Ketapang District & Number of Schools \\
\hline 1 & Benua Kayong & 2 \\
\hline 2 & Delta Pawan & 3 \\
\hline 3 & Jelai Hulu & 1 \\
\hline 4 & Matan Hilir Selatan & 4 \\
\hline 5 & Muara Pawan & 1 \\
\hline 6 & Nanga Tayap & 2 \\
\hline \multirow[t]{2}{*}{7} & Sandai & 1 \\
\hline & Total & 14 \\
\hline
\end{tabular}


Analysis Of Adaptive Physical Education Learning In The Covid-19 Pandemic Period at Ketapang District

From the 14 schools that have filled out the online questionnaire, the results of the adaptive physical education learning questionnaire during the Covid-19 pandemic can be seen in Table 2.

Table 2.

Methods of Teaching Adaptive Physical Education to students during the Pandemic

\begin{tabular}{llc} 
No & \multicolumn{1}{c}{ Information } & Percentage \\
\hline 1 & $\begin{array}{l}\text { Implementation of Adaptive Physical Education Learning based on } \\
\text { the Physical Education Subject Curriculum Physical Education }\end{array}$ & $92.86 \%$ \\
2 & $\begin{array}{l}\text { The current curriculum is not following the conditions and abilities of } \\
\text { each student }\end{array}$ & $60.71 \%$ \\
3 & $\begin{array}{l}\text { Teacher makes The Annual Program (Prota) education learning during } \\
\text { the pandemic Covid-19 }\end{array}$ & $80.36 \%$ \\
4 & $\begin{array}{l}\text { The teacher makes The Semester Program (Promes) for Physical } \\
\text { Education learning during the pandemic }\end{array}$ & $73.21 \%$ \\
\hline & $\begin{array}{l}\text { Teachers make lesson plans with 1 sheet format learning during the } \\
\text { pandemic Covid-19 }\end{array}$ & $53.57 \%$ \\
\hline & Teachers conduct online learning during the pandemic Covid-19 & $92.86 \%$ \\
\hline
\end{tabular}

Based on the data in Table 2, obtained 92.86\% of Primary School Physical Education teachers in Ketapang Regency have been guided by the Physical Education subject curriculum published by the Ministry of Education and Culture of the Republic of Indonesia. $60.71 \%$ of respondents thought that the current curriculum 2013, was has been following the conditions of students, but it needed to be adapted to the conditions of students with disabilities. During the Covid-19 pandemic, as many as $80.36 \%$ of Physical Education teachers have made the Annual Program (Prota), while $73.21 \%$ of Primary School Physical Education teachers have made the Semester Program (Promes). Because the total percentage does not reach $100 \%$, it can be seen that there are still teachers who during the Covid-19 pandemic have not made plans for Prota and Promes according to pandemic conditions, including developing RPP with one sheet, this can be seen in table 2 were in the question the availability of RPP with format 1 sheet only obtained a value of $76.79 \%$. The pandemic causes teachers to change their habits from physical activities in the field to online activities, but as a Physical Education teacher, they must keep their enthusiasm for teaching even though the pandemic conditions and learning is carried out 
Analysis Of Adaptive Physical Education Learning In The Covid-19 Pandemic Period at Ketapang District

online. Meanwhile, the data from the online questionnaire implementation of adaptive physical education learning in schools can be seen in the table shows in table 3.

Table 3.

Methods of Teaching Adaptive Physical Education to students during the Pandemic

$\begin{array}{ll}\text { Method used to teach in Pandemic Covid-19 } & \text { Number of } \\ \text { Respondents }\end{array}$

Assignments Making Practical Tutorial Videos

Making Material Summaries

Providing Assignments through LKS and books distributed to students

Using the Google Classroom Application

Giving assignments through guardians/parents and collecting parents to school

\section{Total Respondents}

Based on the data in Table 3, known that the teaching methods of Adaptive Physical Education carried out by teachers during the Covid-19 pandemic at 14 elementary schools in Ketapang Regency, among others; 1) making material summaries, 2) making practical tutorial videos, 3) giving assignments through worksheets and books that are distributed by the teacher to students, 4) using the google classroom application, and 5) giving assignments through the parents/guardians of the students who are submitted to the school. The highest result on the questionnaire response that was distributed was the method of making a summary, and the lowest was the use of online learning applications. This is possible due to the constraints of internet access in several sub-districts in the Ketapang district. Meanwhile, based on research results (Herlina \& Suherman, 2020) physical education learning during the Covid-19 pandemic can be done by using a model of distance learning and initiating a collaborative approach by involving students' parents through observation sheets of student learning activities. 
Analysis Of Adaptive Physical Education Learning In The Covid-19 Pandemic Period at Ketapang District

Table 4 .

Forms of Adaptive Physical Education Assignments for students during the Pandemic

Form of Assignment

Doing Fields and Multiple-Choice Exercises

Making Sports Field Pictures

Making practice videos of exercise movements at home
Number of Respondents

\section{9}

2

3

14

Based on the data in Table 4, which is about the form of Adaptive Physical education assignments carried out by 14 Elementary Schools in Ketapang Regency, it is obtained information that the form of assignments given to students is to do practice questions in either form or multiple-choice, while some teachers ask students to draw pictures. Sports field. However, in some schools that have easy access to the internet network, the teacher asks students to make a practice video of their own Sports Movement at home. If students do practice questions too often. Students can become unwell due to the absence of physical exercise like what was done before the Covid-19 pandemic so that it can affect the physical and spiritual health conditions of students during the pandemic. This is in line with research (Komarudin \& Prabowo, 2020) conducted at SMA Negeri 1 Bintan Timur, where students' perceptions of the implementation of online learning for sports and health physical education are not yet fully effective and not good. The findings in this study are in line with the results of research (Widiyatmoko \& Hudah, 2017) that in practice or application of character learning by Physical Education teachers, starting from starting learning (warming-up), learning core, and closing (cooling-down) only $65 \%$ of teachers who apply it in learning, while 35\% do not implement these activities. If in offline learning alone, many students are not serious about taking Physical Education and Health Learning, then online learning needs to get more serious attention during the Covid-19 pandemic. This is in line with (Tarigan, 2016) that children with disabilities who have difficulty participating in the Physical Education program are the responsibility of the Physical Education teacher to provide the same service to all students, both disabled and normal, by modifying both equipment, regulations, and playing fields. The Covid-19 pandemic requires teachers to be more creative, innovative, and productive in making learning innovations for students with special needs. 
Table 5.

Constraints experienced in implementing Adaptive Physical Education

Constraints experienced by teachers in adaptive physical education learning during the pandemic

Signals Internet, do not support online learning

Students do not understand the material /video delivered

Material is not conveyed maximally

Facilities Supporting infrastructure that students do not have

Constraints Time for practicing at home is not maximum

Cannot interact with students directly

Lack of guardian responses to online learning

Not all students have cellphones/gadgets
Number of

Respondents

\section{Total Respondents}

3

2

1

1

1

3

1

2

14

In Table 5, was obtained about the obstacles experienced by Physical Education teachers during the Covid-19 pandemic, including; 1) Internet signals do not support online learning, 2) teachers cannot interact directly with students, 3) students do not understand the material/videos conveyed via WhatsApp media or Youtube video links, 4) not all elementary school students have cellphones/gadgets, 5) the absence of supporting facilities and infrastructure for sports activities at students' homes, 6) the time for implementing Physical Education activities at home is not optimal, 7) the parents/guardians are not active enough in online learning. In line with (Tarigan, Junanda, \& Ma'mun, 2019) where the use of modified learning media in volleyball matches affects the courage and learning outcomes of deaf students in under-passing.

\section{CONCLUSIONS AND SUGGESTIONS}

Adaptive Physical Education Learning in Ketapang Regency has been carried out online, where there are still obstacles, namely difficulties in internet connection, low adaptive physical education learning assistance by parents, and the lack of ability to modify learning methods during the Covid-19 pandemic, so learning becomes less 
Analysis Of Adaptive Physical Education Learning In The Covid-19 Pandemic Period at Ketapang District

effective.

Researchers suggest that physical education teachers always develop attractive training methods during the pandemic and learning media that are easily accessible to students in the Ketapang area.

\section{REFERENCES}

Herlina, H., \& Suherman, M. (2020). Potensi Pembelajaran Pendidikan Jasmani Olahraga dan Kesehatan (PJOK) di Tengah Pandemi Corona Virus Disease (COVID)-19 di Sekolah Dasar. Tadulako Journal Sport Sciences And Physical Education, 8(1), 1-7. Retrieved from http://jurnal.untad.ac.id/jurnal/index.php/PJKR/index

Komarudin, K., \& Prabowo, M. (2020). Persepsi siswa terhadap pembelajaran daring mata pelajaran pendidikan jasmani olahraga dan kesehatan pada masa pandemi Covid-19. MAJORA: Majalah Ilmiah Olahraga, 26(2), 56-66.

Ragil, D. S. (2016). Tingkat Keterlaksanaan Pembelajaran Pendidikan Jasmani Bagi Siswa Berkebutuhan Khusus (Penjas Adaptif) di Sekolah Dasar Inklusi se-Kecamatan Sentolo. PGSD Penjaskes, 8, 1-10.

Tarigan, B. (2016). Pendidikan Jasmani Adaptif. (D. Sukyadi \& Y. Mulyadi,Eds.). Bandung: UPI Press.

Tarigan, B., Junanda, H. A., \& Ma'mun, A. (2019). Improving the Quality of Adaptive Health Education Services for Disabled Students (Influence of media in the use of volleyball games on courage and the results of down passing learning of deaf students). Advance in Health Sciences Research in 3rd International Conference on Sport Science, Health, and Physical Education (ICSSHPE 2018), 11, 37-40.

Widiyatmoko, F. A., \& Hudah, M. (2017). Evaluasi Implementasi Pendidikan Nilai Dalam Pembelajaran Penjas. Jurnal Ilmiah Penjas (Penelitian, Pendidikan Dan Pengajaran), 3(1), 44-60. Retrieved from www.beritasatu.com

Wijayanti, D. G. S., Soegiyanto, S., \& Nasuka, N. (2016). Journal of Physical Education and Sport. Journal of Physical Education and Sport, 5(1), 17-23. Retrieved from http://journal.unnes.ac.id/sju/index.php/jpes 